\title{
Hemorrhagic Change
}

National Cancer Institute

\section{Source}

National Cancer Institute. Hemorrhagic Change. NCI Thesaurus. Code C35380.

A morphologic finding indicating a change in a tissue due to vascular injury or leakage. 